\title{
THE SCARLET GENE: BEHAVIORAL GENETICS, CRIMINAL LAW, AND RACIAL AND ETHNIC STIGMA
}

\author{
KAREN ROTHENBERG* AND ALICE WANG**
}

\section{INTRODUCTION}

Imagine that a scientist from the state university asks you and your family to participate in a study on a particular gene variant associated with alcoholism. The project focuses on your ethnic group, the Tracy Islanders, who have a higher incidence of alcoholism, as well as a higher incidence of the gene variant, than the general population. You will not be informed whether you have the gene variant, but your participation in the study might help scientists develop drugs to help individuals control their addiction to alcohol. You have a family history of alcoholism, and you are concerned that your twenty-one-year-old son may be susceptible to the condition as well. Do you agree to participate in the study?

Now imagine that, with your participation, the study concludes that Tracy Islanders with the particular gene variant have a ten percent chance of becoming alcoholics, whereas Tracy Islanders without the gene variant have only a five percent chance. Although the scientists are careful to note that the gene variant exists in the general population and is not "the cause" of alcoholism, the sound-bite reported by the media is that Tracy Islanders are hardwired to become alcoholics.

That same day, your son gets drunk at a bar and pushes an off-duty police officer through a window, killing him. Your son is charged with murder, and his lawyer wants to use his genetic predisposition toward alcoholism as a defense. Some members of your family and community are concerned that this approach will only further stigmatize Tracy Islanders as alcoholics. How do you advise your son and his lawyer?

These scenarios were presented to a panel of scientists, legal experts, journalists, and community leaders in a recent PBS television program entitled

\footnotetext{
Copyright $(\mathcal{C} 2006$ by Karen Rothenberg and Alice Wang

This Article is also available at http://law.duke.edu/journals/lcp.

* Dean and Marjorie Cook Professor of Law, University of Maryland School of Law.

* Staff Attorney, Appellate Division, Public Defender Service for the District of Columbia. The views expressed in this article are those of the authors and do not necessarily represent those of their affiliate institutions.
} 
Genes on Trial: Genetics, Behavior, and the Law.' This article uses the television program as a framework for exploring the implications of behavioral genetics research for the individual, family, community, and society. In particular, it focuses on the unique potential for behavioral genetics research, when placed in the context of criminal law, to stigmatize racial and ethnic minority groups through the blame-shifting mechanisms of genetic reductionism and genetic determinism. Like the scarlet "A" in Nathaniel Hawthorne's famous novel, ${ }^{2}$ DNA associated with criminal or antisocial behavior might become a "scarlet gene" that marks the individual, his family, and his racial or ethnic community as "flawed, compromised, and somehow less than fully human.",3

This article proceeds in six parts. The remainder of Part I summarizes the Genes on Trial program and introduces the issues raised by it. Part II explains why behavioral genetics research tends to focus on discrete and insular populations that overlap with socially constructed racial or ethnic groups. Part III locates behavioral genetics research on a spectrum spanning from singlegene disorders to complex behavioral traits, positing that the behavioral end of the spectrum carries the most potential for stigma. Part IV explores how the blame-shifting mechanisms of genetic reductionism and genetic determinism affect the individual, family, community, and society when genetics research focuses on criminal or antisocial behavior. Part $\mathrm{V}$ analyzes how racial and ethnic stigma arise from behavioral genetics research and perpetuate inequality. Part VI concludes by considering the ethical dilemmas that geneticists face when choosing who and what to study.

$$
* * *
$$

The Genes on Trial program was part of a series of Fred Friendly Seminars entitled Our Genes/Our Choices. ${ }^{4}$ Fifteen panelists were sequestered together for several days and assigned to play roles in the hypothetical scenarios described above. Professor Charles Ogletree of Harvard Law School moderated the discussion by posing questions and introducing factual

1. Genes on Trial: Genetics, Behavior, AND the Law (Films for the Humanities \& Sciences 2004) (transcript available at http://www.pbs.org/fredfriendly/ourgenes/transcripts/GENES_ TRANSCRIPT.pdf).

2. Nathaniel Hawthorne, The Scarlet LeTter (William Charvat et al. eds., Ohio State University Press 1962) (1850).

3. John F. Dovidio et al., Stigma: Introduction and Overview, in THE SocIAL PSYCHOLOGY OF STIGMA 1, 3 (Todd F. Heatherton et al. eds., 2000).

4. Our Genes/Our Choices, http://www.pbs.org/inthebalance/archives/ourgenes/index.html (last visited Oct. 1, 2005). The other two programs in the series were WHO GETS To KNOW? GENETICS AND PRIVACY (Films for the Humanities \& Sciences 2004) (transcript available at http:/www.pbs.org/fredfriendly/ourgenes/transcripts/WHOKNOWS_TRANSCRIPT.pdf) and MAKING BETTER BABIES: GENETICS AND REPRODUCTION (Films for the Humanities \& Sciences 2004) (transcript available at http://www.pbs.org/fredfriendly/ourgenes/transcripts/BABIES TRANSCRIPT.pdf). 
complications into the scenarios. The purpose of this role-playing format was to create a "human drama" that would help both the panelists and the audience "to consider the issues in all their complexity."

The program began with a discussion of the implications of participating in behavioral genetics research. Stanley Crouch, a columnist for the New York Daily News, and Karen Rothenberg played the roles of the Tracy Islander parents who were asked to participate in a study on a gene variant associated with alcoholism. While they were concerned about their son's growing symptoms of alcoholism, they were also wary of the study's potential impact on their family. Supreme Court Justice Stephen Breyer played the role of the uncle who encouraged the family to participate in the research for its contribution to scientific knowledge, while Professor Patricia King of Georgetown University Law Center played the role of another family member who feared that the research would stigmatize all Tracy Islanders as alcoholics. Dean Hamer, a geneticist at the National Cancer Institute, and David Goldman, a geneticist at the National Institute on Alcohol Abuse and Alcoholism, played the roles of university scientists, while Francis Collins, Director of the National Human Genome Research Institute, played the role of the university president.

When the conversation turned to the potential impact of the research on the Tracy Islander community, Reverend Colin Gracy of Northeastern University, playing the role of a religious leader in the Tracy Islander community, questioned the study's focus on Tracy Islanders, as did Evan Balaban, a neuroscientist at the College of Staten Island at the City University of New York, and Nadine Strossen, President of the American Civil Liberties Union, who expressed concern about the status of Tracy Islanders as a historically oppressed immigrant group. Barry Mehler, a professor of history at Ferris State University, questioned whether discovering a gene variant correlated with alcoholism would have any positive impact on social problems associated with alcoholism, such as homelessness.

The program then considered the media's role in interpreting and disseminating the results of the research. Playing the role of a journalist covering the study, Gwen Ifill, the managing editor of Washington Week, defended the media's role in exploring the impact of the study on the Tracy Islander community, while Alan McGowan, President of the Gene Media Forum, criticized unscrupulous journalists for reporting that "the gene for alcoholism" had been discovered. Meanwhile, Charles Ogletree switched into the role of "Brad Blueblood," the host of a syndicated show called I'm Always Right, who treated the study as evidence that Tracy Islanders were inherently inferior.

On the same day the study was released, the fictional Tracy Islander parents learned that their son Joseph had killed an off-duty police officer while drunk at

5. About Fred Friendly Seminars, http:/www.pbs.org/inthebalance/archives/ourgenes/about.html (last visited Oct. 1, 2005). 
a bar and was being charged with murder. Playing the role of Joseph's defense attorney, Johnnie Cochran explored the possibility of a "DNA defense," suggesting that Joseph was not responsible for murder because his genetic predisposition toward alcoholism had "taken away his free will." Meanwhile, playing the role of the prosecutor, attorney Victoria Toensing argued that Joseph should not be released on bail because, by his own admission, he had a genetic proclivity to drink and to become violent.

The program concluded with a new proposal to study the genetic influences on impulse control and aggression. While several panelists expressed skepticism about the value of such research, others emphasized the potential for behavioral genetics research to remedy social problems and to alleviate human suffering. Using the program as a springboard, this article explores how genetics research on criminal or antisocial behavior has the unique potential to ENTIAL TO stigmatize racial and ethnic minority groups in a manner that both reflects and reinforces social inequality.

\section{II}

\section{BEHAVIORAL GENETICS RESEARCH AND "DISCRETE AND INSULAR MINORITIES"}

From a geneticist's perspective, the Tracy Islanders are very interesting because they had a very small set of original founders, so there is less heterogeneity than we would expect to find in their DNA-which, simply put... means we have a better chance of finding an answer than if we look at a very outbred group with a lot of different genetic contributions coming from a lot of places.

- Francis Collins, Director, National Human Genome Research Institute ${ }^{7}$

One of the issues raised in the Genes on Trial program was why the genetics research on alcoholism "targeted" an ethnic minority group like the Tracy Islanders-an issue that becomes even more acute in the context of criminal law. Several factors explain why the intersection of behavioral genetics research and criminal law disproportionately affects racial and ethnic minority groups. First, genetics research tends to focus on discrete and insular populations that share a common ancestry and that often overlap with socially constructed racial or ethnic minority groups. Second, the study of genetic differences between racial or ethnic groups appeals to the persistent impulse in our society to explain racial and ethnic differences in biological terms. Finally, because racial and ethnic minority groups are disproportionately represented in the criminal justice system, efforts to analyze the DNA of criminals will inevitably be skewed toward these groups.

6. United States v. Carolene Prods. Co., 304 U.S. 144, 152 n.4 (1938). See also infra note 24 and accompanying text.

7. GENES ON TRIAL, supra note 1 (playing the role of the university president). 


\section{A. Race, Ethnicity, and Genetics}

While race and ethnicity are difficult and contentious terms to define, this article treats them both as social constructs with overlapping meanings. Whereas race refers to groups identified by physical traits and geographic origin, ethnicity refers to groups sharing a common kinship, nationality, religion, language, or culture." Because these categories are socially constructed, their definitions depend on the social context. What is considered "black" in the United States, for example, might be considered "white" in Brazil." The U.S. Census Bureau recognizes five racial groups ("American Indian or Alaska Native," "Asian," "Black or African American," "Native Hawaiian or Other Pacific Islander," and "White") and one ethnic group ("Hispanic or Latino")." Although race and ethnicity are distinct concepts, this article analyzes them together for the purpose of exploring the impact of behavioral genetics on populations that have socially constructed group identities.

While recent forensics research suggests that race and ethnicity can be identified by DNA analysis, ${ }^{12}$ it is commonly accepted among geneticists that race and ethnicity are not biologically determined categories and that greater genetic variation exists within racial groups than between them. ${ }^{13}$ Nevertheless, race and ethnicity can serve as rough proxies for ancestry and may therefore be salient to genetics research. ${ }^{14}$ For example, a particular racial or ethnic group may exhibit a higher incidence of a particular gene variant than other groups, as

8. See Stephen Cornell \& Douglas Hartmann, Ethnicity and RaCe: Making IDENTITIES IN A CHANGING WORLD 25-34 (1998).

9. See id. at 15-25. The federal hate crimes statute offers the following definitions: "the term 'racial group' means a set of individuals whose identity as such is distinctive in terms of physical characteristics or biological descent," 18 U.S.C. $\$ 1093(6)$ (2000), and "the term 'ethnic group' means a set of individuals whose identity as such is distinctive in terms of common cultural traditions or heritage," Id. at \$1093(2).

10. Michael J. Bamshad \& Steve E. Olson, Does Race Exist?, 289 SCI. AM. 78, 80 (2003).

11. See U.S. Census Bureau, Racial and Ethnic Classifications Used in 2000 Census and Beyond (Apr. 12, 2000), http://www.census.gov/population/www/socdemo/race/racefactcb.html; Revisions to the Standards for the Classification of Federal Data on Race and Ethnicity, 62 Fed. Reg. 58,782 (Oct. 30 , 1997). The Office of Management and Budget, which sets the standards used in the U.S. Census, defines "Hispanic or Latino" as "a person of Cuban, Mexican, Puerto Rican, South or Central American, or other Spanish culture or origin, regardless of race." Id. at 58,789.

12. See, e.g., B. Devlin \& Neil Risch, Ethnic Differentiation at VTNR Loci, with Specific Reference to Forensic Applications, 51 AM. J. HuM. Genetics 534 (1992); Alex L. Lowe et al., Inferring Ethnic Origin by Means of an S.T.R. Profile, 119 FORENSIC SCI. INT'L 17 (2001). For a discussion of this research, see Troy Duster, Selective Arrests, an Ever-Expanding DNA Forensic Database, and the Specter of an Early-Twenty-First-Century Equivalent of Phrenology, in DNA AND THE CRIMINAL JUSTICE SYSTEM 313, 322-27 (David Lazer ed., 2004).

13. See, e.g., JosePh L. Graves, The EMPEROR's New Clothes: Biological Theories of RaCE AT THE MillenniUm 1-7, 193-97 (2001); Guido Barbujani et al., An Apportionment of Human DNA Diversity, 94 PROC. OF THE NAT'L ACAD. OF SCI. 4516 (1997); Eliot Marshall, Cultural Anthropology: DNA Studies Challenge the Meaning of Race, 282 SCIENCE 654 (1998).

14. See Erik Lillquist \& Charles A. Sullivan, The Law and Genetics of Racial Profiling in Medicine, 39 HARV. C.R.-C.L. L. REv. 391, 408-09 (2004); cf. Deborah Hellman, Two Types of Discrimination: The Familiar and the Forgotten, 86 CAL. L. REV. 315 (1998) (distinguishing between proxy and nonproxy discrimination). 
illustrated by the example of "the alcoholism gene" and the fictional Tracy Islanders in the Genes on Trial program. Real-life examples of this phenomenon include the sickle-cell anemia gene in African Americans and the Tay-Sachs gene in Ashkenazi Jews. ${ }^{15}$ This phenomenon does not indicate, however, that race and ethnicity are genetically defined; rather, it reflects evolutionary forces such as genetic drift, the founder effect, and the bottleneck effect that affect the genetic composition of small, reproductively isolated populations. ${ }^{16}$

Genetic drift is the fluctuation of gene frequencies within a small population caused by random mutations. ${ }^{17}$ One form of genetic drift, known as the founder effect, occurs when a population originates from a small set of ancestors and maintains a random mutation through inbreeding because of voluntary or forced isolation. ${ }^{18}$ This mechanism helps explain, for example, the high incidence of the Tay-Sachs gene among Ashkenazi Jews ${ }^{19}$ and the virtual absence of the B blood type among Native Americans. ${ }^{20}$ Another form of genetic drift, known as the bottleneck effect, occurs when a catastrophic event, such as famine, war, or an epidemic, wipes out a large portion of the population, thereby changing the composition of the gene pool that will serve as the source of repopulation. ${ }^{21}$ In both the founder effect and the bottleneck effect, it is the inbreeding within a small population that is responsible for the unusually high incidence of the mutation, not the genetic distinctiveness of the population itself. $^{22}$

In seeking to estimate the genetic influence on a particular trait, behavioral geneticists tend to study populations with a relatively homogeneous gene pool in order to isolate the effects of a particular gene variant on that behavioral trait. $^{23}$ Accordingly, they often focus on small, reproductively isolated populations that share a common ancestral background. Such populations tend to overlap with socially constructed racial or ethnic minority groups-what are

15. See Lillquist \& Sullivan, supra note 14 , at 410.

16. See id. at 395, 418-26; see also Jacqueline Stevens, Racial Meanings and Scientific Methods: Changing Policies for NIH-Sponsored Publications Reporting Human Variation, 28 J. HEALTH POL. POL'Y \& L. 1033, 1046-48 (2003).

17. See Friedrich VOGEL \& ARno G. Motulsky, Human Genetics: Problems and APPROACHES 504-05 (2d ed. 1986); see also STEVE OLSON, MAPPING HUMAN History: Discovering THE PAST THROUGH OUR GENES 164-65 (2002) ("Genetic drift is more obvious in such small interbreeding populations because an individual who has many children can flood a population with distinctive genetic variants.").

18. See Karen H. Rothenberg \& Amy B. Rutkin, Toward a Framework of Mutualism: The Jewish Community in Genetics Research, 1 COMMUNITY Genetics 148, 150 (1998). For a technical explanation of how rare recessive diseases can become prevalent in small populations due to the founder effect, see VOGEL \& MOTULSKY, supra note 17, at 508.

19. Lillquist \& Sullivan, supra note 14 , at 425.

20. See Anthony J.F. GRIFFITHS et al., An InTRODUCTION to GENETIC ANALYSis 807 (6th ed. 1996).

21. See Rothenberg \& Rutkin, supra note 18 , at 150 .

22. See Stevens, supra note 16 , at 1046.

23. See Lon R. Cardon, Practical Barriers to Identifying Complex Trait Loci, in BEHAVIORAL Genetics in the Postgenomic ERA 55, 61 (Robert Plomin et al. eds., 2003). 
known in constitutional law as "discrete and insular minorities." 24 This overlap is significant because the very features of discreteness and insularity that make a population useful for genetics research are also the features that make them vulnerable to societal and governmental discrimination.

In genetics, populations affected by the founder and bottleneck effects are "discrete" in that they can be identified by a common ancestral and geographical origin, and they are "insular" in that they historically have been reproductively isolated from the mainstream population. In constitutional law, racial and ethnic minority groups are "discrete" in that they generally can be identified by a distinct and often immutable trait, and they are "insular" because they historically have been segregated from mainstream society and excluded from the political process. ${ }^{25}$ Of course, the genetic, social, and legal categories do not overlap entirely. Latinos, for example, are discrete and insular minorities in the constitutional sense but not in the genetic sense because their gene pool is relatively diverse. Likewise, while the Amish are discrete and insular minorities in the genetic sense because their culture forbids intermarriage, they are not considered racial or ethnic minorities in the constitutional sense because they cannot be identified by a distinct physical trait and historically have not been subject to the widespread discrimination and forced segregation that African Americans, Jews, Latinos, Asians, and Native Americans have experienced. Nonetheless, many of the discrete and insular populations studied in behavioral genetics happen to be racial or ethnic minority groups that have been subject to discrimination and segregation. Because such treatment has included eugenics in the form of forced sterilization, anti-miscegenation laws, and exclusionary immigration policies, genetics research that focuses on these groups comes with specific historical baggage that contributes to racial and ethnic stigma. ${ }^{26}$

\section{B. The Allure of Genetic Difference}

Besides the methodological advantage of studying discrete and insular minority groups to isolate the effect of a particular gene variant, there is the allure of explaining racial and ethnic differences in terms of genetics. ${ }^{27}$ In their book The DNA Mystique, Dorothy Nelkin and Susan Lindee document how the

24. United States v. Carolene Prods. Co., 304 U.S. 144, 152 n.4 (1938).

25. See generally JOHN HART ELY, DEMOCRACY AND DISTRUST: A THEORY OF JUDICIAL REVIEW 145-70 (1980). In defining "suspect classifications" that warrant strict judicial scrutiny under the Equal Protection Clause of the Fourteenth Amendment, the Supreme Court has identified three criteria for discrete and insular minorities: those who exhibit "obvious, immutable, or distinguishing characteristics that define them as a discrete group"; those who historically have been subject to discrimination; and those who are a "minority or politically powerless." Lyng v. Castillo, 477 U.S. 635, 638 (1986).

26. See Allen Buchanan et Al., From Chance to Choice: Genetics and Justice 27-46 (2000); Rothenberg \& Rutkin, supra note 18, at 150. For cases discussing these policies, see Loving $v$. Virginia, 388 U.S. 1 (1967) (anti-miscegenation); Buck v. Bell, 274 U.S. 200 (1927) (forced sterilization); and The Chinese Exclusion Case, 130 U.S. 581 (1889) (immigration).

27. See BUCHANAN ET AL., supra note 26, at 23; Stevens, supra note 16, at 1072. 
rhetorical and imagistic power of the gene has permeated American culture, especially in explaining and justifying social inequalities. ${ }^{28}$ It is no surprise, then, that the focus on racial and ethnic minority groups in behavioral genetics research is readily accepted and appropriated by a popular culture that embraces the idea of genetic differences between socially constructed groups.

This phenomenon is reflected in the growing body of research on the genetic bases for differences in disease susceptibility and drug reactions among racial and ethnic groups. ${ }^{29}$ One of the most well-known examples is research on the BRCA mutations associated with breast cancer in Ashkenazi Jewish women. ${ }^{30}$ Other examples include research on a genetic link to prostate cancer in African American men, genetic mutations linked to asthma in individuals of Middle Eastern descent, and a gene variant associated with scleroderma in Native Americans. ${ }^{31}$ Based on genetics research on variations in drug reactions among different racial and ethnic groups, ${ }^{32}$ pharmaceutical companies are now marketing drugs for specific racial and ethnic groups, such as BiDil, a hypertension drug targeted at African Americans. ${ }^{33}$ On a broader scale, the newly launched International HapMap Project seeks to "find genes that affect health, disease, and individual responses to medications and environmental factors" by studying four population groups from Nigeria, Japan, China, and the United States. ${ }^{34}$

Such research is driven in part by government policies that seek to include racial and ethnic minority groups in medical research. As mandated by federal statute, $^{35}$ for example, the National Institutes of Health (NIH) requires all federally funded clinical research to include racial and ethnic minorities as subjects unless such inclusion is "inappropriate," and to review any evidence of

28. Dorothy Nelkin \& M. SUSAN LindeE, The DNA Mystique: The Gene as a Cultural ICON (1995).

29. Lillquist \& Sullivan, supra note 14, at 393; Stevens, supra note 16, at 1034.

30. See generally Karen H. Rothenberg, Breast Cancer, The Genetic "Quick Fix," and the Jewish Community, 7 HEALTH MATRIX 98 (1997); Stevens, supra note 16, at 1042. For a technical explanation of the BRCA mutations, see JACK J. PASTERNAK, AN INTRODUCTION TO HUMAN MOLECULAR GENETICS: MECHANISMS OF INHERITED DISEASES 490-92 (2d ed. 2005).

31. Stevens, supra note 16 , at 1056-57. One of the most controversial examples is the "slavery hypothesis," which seeks to explain the higher incidence of hypertension among African Americans by positing that when their ancestors were brought as slaves from Africa to America, those with genetic predispositions toward salt retention were more likely to survive the arduous voyage and thus form the original gene pool of African Americans. See id. at 1071-73; Stephen J. Dubner, Toward a Unified Theory of Black America, N.Y. TIMES MAG., Mar. 20, 2005, at 54 (describing the work of Harvard economist Roland Fryer); Jay S. Kaufman, The Anatomy of a Medical Myth, SOCIAL SCIENCE RESEARCH COUNCIL, http://raceandgenomics.ssrc.org/Kaufman (last visited Oct. 1, 2005).

32. See Stevens, supra note 16 , at 1058-59.

33. Sally L. Satel, I Am a Racially Profiling Doctor, N.Y. Times MAG., May 5, 2002, at 58.

34. International HapMap Project, About the HapMap (2002), http://www.hapmap.org/thehap map.html.en.

35. NIH Revitalization Act of 1993, 42 U.S.C. $\$ 289 a-2$ (2000). 
"significant" racial or ethnic differences in the intervention effect. ${ }^{36}$ Similarly, the Food and Drug Administration advocates the collection of race and ethnicity data in all clinical trials. ${ }^{37}$ As a form of affirmative action in medical research, these guidelines engender tension analogous to that surrounding racial and ethnic affirmative action in higher education and employment. While colorblindness in those contexts may only perpetuate "the effects of centuries of law-sanctioned inequality," ${ }^{, 38}$ singling out racial and ethnic minorities for special treatment threatens to stigmatize them as "undeserving." 39 Similarly, when placed in the context of genetics research, the focus on racial and ethnic minorities may be a mixed blessing: while it may draw attention and resources to problems afflicting the minority community, it may also stigmatize the community as genetically inferior and reify the socially constructed notion of race. ${ }^{40}$ This tension exists, for example, in the Jewish community regarding research on the BRCA gene variants associated with breast cancer. While some members of the community welcome such research for its potential to advance both the community's health and society's scientific knowledge, others view the research as targeting Jews for genetic screening in the historical shadow of Nazi eugenics."

A related concern in the African American community is that genetics research on racial differences in health traits will legitimize genetics research on racial differences in behavioral traits. ${ }^{42}$ Indeed, the allure of genetic difference is not limited to medical research. Traits that recently have been attributed to heredity in the mass media include aggression, intelligence, homosexuality, impulsiveness, exhibitionism, family loyalty, addiction, religiosity, deviance, learning disability, and happiness. ${ }^{43}$ As illustrated by the controversial bestseller The Bell Curve, ${ }^{44}$ perhaps one of the most pervasive and perverse ideas in American society is that blacks are genetically less intelligent than whites and Asians. ${ }^{45}$ This impulse to seek genetic explanations for racial and ethnic

36. National Institutes of Health, NIH Policy and Guidelines on the Inclusion of Women and Minorities as Subjects in Clinical Research (Oct. 2001), http:/grants.nih.gov/grants/funding/women_min/guidelines_amended_10_2001.htm.

37. See Draft Guidance for Industry on the Collection of Race and Ethnicity in Clinical Trials for FDA Regulated Products, 68 Fed. Reg. 4788 (Jan. 30, 2003).

38. Gratz v. Bollinger, 539 U.S. 244, 298-304 (2003) (Ginsburg, J., dissenting).

39. Grutter v. Bollinger, 539 U.S. 306, 373 (2003) (Thomas, J., dissenting).

40. See Lillquist \& Sullivan, supra note 14 , at $399-400$.

41. See Rothenberg \& Rutkin, supra note 18, at 149-50; Marc D. Schwartz, Karen Rothenberg, Linda Joseph, Judith Benkendorf, \& Caryn Lerman, Consent to the Use of Stored DNA for Genetics Research: A Survey of Attitudes in the Jewish Population, 98 AM. J. MED. GENETICS 336 (2001).

42. See Lillquist \& Sullivan, supra note 14, at 392, 399-40.

43. See Dorothy Nelkin, Behavioral Genetics and Dismantling the Welfare State, in BEHAVIORAL Genetics: The Clash of Culture and Biology 156, 156 (Ronald A. Carson \& Mark A. Rothstein eds., 1999) [hereinafter BEHAVIORAL GENETICS].

44. Richard J. HerRnstein \& Charles Murray, The Bell Curve: Intelligence and ClaSS STRUCTURE IN AMERICAN LIFE (1994).

45. See GRAVES, supra note 13, at 157-72; NELKIN \& LINDEE, supra note 28, at 112-17. 
differences may explain why behavioral genetics research that focuses on racial and ethnic minority groups is so readily sensationalized in the popular press.

\section{Racial and Ethnic Bias and the Criminal Justice System}

When placed in the context of criminal law, behavioral genetics research is even more likely to focus on racial and ethnic minority groups. Although "stereotypes about race and crime may make it more likely that researchers will look for a gene for aggression or criminality in a minority population," more likely scenario is that genetics research on criminal behavior will focus on blacks and Latinos simply because they are disproportionately represented in the criminal population. From 1990 to 2004, blacks were five times more likely than whites to be incarcerated, ${ }^{47}$ and in 2000 , blacks and Latinos comprised $63 \%$ of incarcerated adults, even though together they represented only $25 \%$ of the total population. ${ }^{48}$

Attributing these trends to the War on Drugs, racial profiling, discriminatory sentencing, and general racial bias in the criminal justice system, sociologist Troy Duster warns that because African Americans are disproportionately represented in the criminal justice system, behavioral genetics research relying on the DNA samples of convicted criminals will inevitably be skewed toward that population. ${ }^{49}$ All fifty states, along with the U.S. Army and the FBI, now contribute to the Combined DNA Index System (CODIS), a national database containing the DNA profiles of nearly 2.5 million convicted offenders. ${ }^{50}$ Although currently used only for identification and forensic purposes, these DNA profiles could potentially be used for behavioral genetics research, resulting in a study implicitly focusing on African Americans and Latinos. ${ }^{51}$ The results of that study, in turn, could stigmatize all African Americans and Latinos as prone to criminal behavior, thereby reinforcing existing stereotypes and promoting discrimination in other contexts.

46. Lori B. Andrews, Predicting and Punishing Antisocial Acts: How the Criminal Justice System Might Use Behavioral Genetics, in BEHAVIORAL GENETICS, supra note 43, at 116, 133.

47. Bureau of Justice Statistics, U.S. Department of Justice, Blacks Were Two Times More Likely Than Hispanics and Five Times More Likely Than Whites To Be in Jail (Apr. 24, 2005), http://www.ojp.usdoj.gov/bjs/glance/jailrair.htm.

48. Human Rights Watch, Race and Incarceration in the United States (Feb. 27, 2002), http://www.hrw.org/backgrounder/usa/race.

49. See Duster, supra note 12, at 316-22, 328-29; Troy Duster, Genetics, Race, and Crime: Recurring Seduction to a False Precision, in DNA ON TRIAL: GENETIC INFORMATION AND CRIMINAL JusTICE 129, 132-33 (Paul R. Billings ed., 1992); Troy Duster, Race and Reification in Science, 307 SCIENCE 1050, 1051 (2005); see also Andrews, supra note 46, at 134.

50. Federal Bureau of Investigation, National DNA Index System (July 2005), http://www.fbi.gov/hq/lab/codis/national.htm.

51. See David Kaye, Behavioral Genetics Research and Criminal DNA Databases, 69 LAW \& CONTEMP. PROBS. 361 (Winter/Spring 2006). 
III

\section{From Disease to BeHa vior: THE SPECTRUM OF GENETICS RESEARCH}

[Glenetics is an incredibly powerful science when... [we] know what we're studying. When we have a condition that is medically defined, like heart disease, we have a clearly defined population of things that we're trying to study and learn about. When we move to something like alcoholism, that may be a whole lot more nebulous, [but] at least there is clinical agreement on patterns of behavior that constitute a problem. Now, we have moved into a brand new arena. We are using terms- "impulsiveness," "aggression"-

that are very difficult to define in the operational ways that scientists need to define things.

- Evan Balaban, Professor, College of Staten Island, City University of New York ${ }^{52}$

The Genes on Trial program concluded with a hypothetical proposal to study the genetic bases of impulsiveness and aggression. As reflected in the skepticism expressed by several of the panelists, the strength and impact of genetics research vary along the spectrum of traits that are studied. As one moves toward the behavioral end of the spectrum, the genetic influence on a trait becomes more uncertain and difficult to isolate, while the stigma associated with such influence becomes more significant. Because criminality is a stigmatic trait, any research on the genetic influence on criminal behavior threatens to stigmatize the population being studied.

\section{A. The Spectrum of Genetics Research}

Genetic research exists on a spectrum that varies in the complexity and precision of the traits being studied. At one end of the spectrum is the study of single-gene disorders, such as sickle-cell anemia and Huntington's disease, which are caused by a single gene variant. Even at this end of the spectrum, however, where the relationship between genotype and phenotype is the closest, geneticists cannot always predict with certainty when the condition will develop or how severe it will be. ${ }^{53}$

Next on the spectrum is the study of complex medical diseases, such as cancer, caused by the interaction of multiple genetic and environmental factors. Although a single gene variant, such as the BRCA mutations associated with breast cancer, may increase the probability of developing the disease, it remains difficult to isolate the effect of the mutation from that of other genetic and environmental factors. $^{54}$ Thus, even if an individual has the gene variant associated with cancer, one cannot predict whether that individual will actually develop cancer, much less when she will develop it and how severe it will be. ${ }^{s s}$

52. GENES ON TRIAL, supra note 1.

53. Mark A. Rothstein, Behavioral Genetic Determinism: Its Effects on Culture and Law, in BehAVIORAl Genetics, supra note 43, at 89, 92; Francis S. Collins et al., Heredity and Humanity, NEW REPUBLiC, June 25, 2001, at 27-28.

54. See Rothstein, supra note 53, at 92-93.

55. Rothenberg \& Rutkin, supra note 18 , at 151. 
Further on the spectrum is the study of complex behavioral conditions or diseases, such as alcoholism, drug addiction, and depression. The genetic influence on these conditions is even more difficult to isolate because their symptoms often involve an element of individual choice. Moreover, such conditions are more elusive research subjects because they are more difficult to define and to diagnose than medical diseases like hypertension and breast cancer. Nevertheless, as Evan Balaban pointed out during the Genes on Trial program, these conditions at least have clinical definitions upon which scientists can agree.

Finally, at the other end of the spectrum is the study of behavioral traits, such as aggression, intelligence, and impulsiveness. Like behavioral conditions or diseases, these traits are influenced not only by genetic and environmental factors, but also by individual choices, thus making their heritability difficult to identify. And because of their social and political implications, the definitions of these traits are often as hotly contested as their heritability. ${ }^{56}$ Thus, behavioral traits are the most indeterminate and controversial subjects of genetics research. At the same time, they may be the most relevant to criminal law. Although genetic disorders like Huntington's disease and XYY trisomy have formed the bases of criminal defenses in the past, ${ }^{57}$ criminal law is now particularly interested in behavioral conditions that contribute to violence, such as alcoholism and mental illness, and antisocial behavioral traits, such as aggression..$^{58}$

\section{B. The Stigma of Behavior}

The behavioral end of the spectrum of genetics research is not only the most scientifically problematic, but also the most potentially stigmatic. As explained above, behavioral traits are not as precisely defined as diseases and thus are subject to manipulation and misunderstanding. Moreover, because behavioral traits involve a strong element of individual choice, they are more closely associated with fault, even if they are deemed genetic. Ironically, the weaker the causal link between the gene and the condition, the more stigmatizing the gene may be, since those who carry the gene are grouped with those who are at

56. See Rothstein, supra note 53, at 93. The line between behavioral conditions or diseases and behavioral traits is blurry and tentative; it may well be that if research were to definitively link aggression to a particular gene, it would be considered a disease. However, it is useful for the purpose of this article to distinguish between conditions or diseases that have clinical definitions on which scientists commonly agree and traits that lack operational definitions and criteria for diagnosis.

57. See Ted Peters, Playing God? Genetic Determinism And Human Freedom $69-72$ (2d ed. 2003); Andrews, supra note 46, at 124-26. For examples of defenses based on Huntington's disease, see United States v. Click, 807 F.2d 847 (9th Cir. 1987); Caldwell v. State, 354 S.E.2d 124 (Ga. 1987); Scammahorn v. State, 506 N.E.2d 1097 (Ind. 1987); and People v. Ponke, No. 180310, 1997 WL 33354421 (Mich. Ct. App. Jan. 24, 1997). For examples of defenses based on XYY trisomy, see People v. Tanner, 91 Cal. Rptr. 656 (Cal. Ct. App. 1970); Millard v. State, 261 A.2d 227 (Md. Ct. Spec. App. 1970); People v. Yukl, 372 N.Y.S.2d 313 (N.Y. Sup. Ct. 1975); and State v. Roberts, 544 P.2d 754 (Wash. Ct. App. 1976).

58. See, e.g., PETERS, supra note 57, at 77 (discussing the connection between crime and alcohol). 
"fault" for their condition. For example, as long as some cases of alcoholism can be attributed entirely to individual choice, alcoholics who are genetically predisposed toward the condition bear the burden of demonstrating that they, unlike their counterparts, did not "choose" to become alcoholics-a burden that individuals with sickle-cell anemia, for example, never have to bear.

Furthermore, traits that potentially threaten society, such as aggression, are more stigmatic than traits that potentially threaten individual health, such as Tay-Sachs disease..$^{59}$ Whereas the latter is a basis for making individual decisions about marriage and childbearing, ${ }^{60}$ the former is a basis for making social policies about surveillance and preventive detention. ${ }^{61}$ Similarly, stigma associated with criminal or antisocial behavior is more far-reaching and disabling than stigma associated with disease because one's behavior is relevant to a wider range of social contexts. While there already is extensive literature on the potential for genetic discrimination in insurance and employment, genetics information has many other potential applications, such as in educational placement, tort liability, loan approval, and child custody. ${ }^{62} \mathrm{~A}$ genetic predisposition toward impulsiveness, for example, might not only increase one's car insurance rates but also count against one's creditworthiness in a mortgage application. More immediately, many of the bases for termination of parental rights, such as cruelty, alcoholism, mental illness, sexual promiscuity, and criminal activity, are traits being studied in behavioral genetics research. ${ }^{63}$ Because a genetic predisposition toward criminal or antisocial behavior is relevant to nearly every aspect of life, the stigma associated with that predisposition is especially threatening.

\section{The Faulty Gene: Reductionism, Determinism, and Blame Shifting}

Let's say you do this study and you find out that our family or groups of families have these predispositions [toward alcoholism]. I'm worried he's going to drink more because now he's going to have an excuse. And he's going to say, "See, I'm not a bad guy. You did it, Mom and Dad, both of you did it to [me]."

— Karen Rothenberg, Dean, University of Maryland School of Law ${ }^{64}$

59. Cf. id. at 72 ("If we carry a defective gene for breast cancer, then we certainly can feel empathy for someone else who carries the gene for cystic fibrosis. But if that other person carries a gene predisposing him or her to harm us, then this adds an additional element of considerable consequence."). But see id. at 66-67 (noting that individuals with Huntington's disease are stigmatized as violent).

60. See, e.g., Rothenberg \& Rutkin, supra note 18 , at 151.

61. See Andrews, supra note 46, at 132-38.

62. See id. at 131, 138; Rothstein, supra note 53, at 107.

63. See Andrews, supra note 46 , at 138 . For a discussion of statutes and case law governing the termination of parental rights based on behavioral traits, see Sherry S. Zimmerman, Annotation, Parents' Mental Illness or Mental Deficiency as Ground for Termination of Parental Rights, 113 A.L.R. 5 th 349 (2003).

64. GENES ON TRIAL, supra note 1 (playing the role of the mother). 
What the study tells me is that your problems are not the result of job discrimination; it's not the result of any kind of ethnic bias; it's not the result of poverty or anything else. The problem is inside of you. It's not the environment. It's you.

- Charles Ogletree, Professor, Harvard Law School ${ }^{65}$

[T]he flip side of the defense of this particular individual is an indictment, so to speak, of not only him but the entire community.

- Nadine Strossen, President, American Civil Liberties Union ${ }^{66}$

As illustrated by the Genes on Trial program, behavioral genetics research, like other genetics research, is vulnerable to the fallacies of genetic reductionism and genetic determinism. By overstating the genetic influence on human behavior, these fallacies shift blame among the individual, family, community, and society. Like the individual's decision to participate in behavioral genetics research, the individual's decision to use such research to support a criminal defense can operate as a double-edged sword: while it may mitigate his culpability by shifting blame away from his "free will," it may also stigmatize him, his family, and his racial or ethnic community as being prone to criminal behavior.

\section{A. Genetic Reductionism, Genetic Determinism, and Blame Shifting}

Genetic reductionism is the impulse to treat genetics, or even a single gene, as the sole cause of a particular trait, discounting the interaction of other genes, the environment, and "free will." The idea of "the alcoholism gene" is an example of genetic reductionism, as it treats alcoholism as a single-gene disorder unaffected by other genes, the environment, or individual choice. Genetic determinism is the impulse to treat DNA as destiny, discounting the possibility of deviating from one's genetic predisposition. ${ }^{68}$ The idea that an individual is "hardwired" to become an alcoholic is an example of genetic determinism, as it suggests that a predisposition toward alcoholism cannot be changed by individual choice or social intervention. ${ }^{69}$ Together, genetic reductionism and genetic determinism describe different aspects of the same fallacy: the overemphasis on the influence of genes on human behavior. ${ }^{70}$

65. Id. (playing the role of "Brad Blueblood").

66. Id.

67. Rothenberg, supra note 30 , at $102-03$ ("Genetic reductionism results when all traits, health problems, and behaviors become attributable to genes and no attention is paid to other potential factors.").

68. See id. ("Genetic determinism results when an individual believes her future is defined and predicted by genetic makeup and cannot be changed.").

69. See NELKIN \& LINDEE, supra note 28, at 195-96 "Traits that are genetic appear as immutable, deeply resistant to change initiated through individual action or external intervention. ... The ideology of genetic essentialism encourages submission to nature and to constraints on the possibilities for social change.").

70. See Rothenberg, supra note 30 , at $102-03$ ("Genetic myopia is a condition that results from viewing everything from the perspective of genetics."). Dorothy Nelkin and Susan Lindee call this condition "genetic essentialism," which "reduces the self to a molecular entity, equating human beings, 
Whereas genetic reductionism is a backward-looking framework for understanding the cause of a trait, genetic determinism is a forward-looking framework for predicting the future. Both are appealing in part because they "extend the certainty and predictability of science to troubling and controversial terrains." They also reflect the emphasis in current American political culture on individual responsibility, as opposed to societal or governmental intervention. ${ }^{72}$

Because the concept of fault is closely linked to the concept of causation, ${ }^{73}$ and because genetic reductionism and genetic determinism treat the gene as the ultimate and determinative cause of a particular behavior, they shift blame for the behavior away from both individual "free will" and the environment created by the family, community, and society. ${ }^{74}$ In the context of criminal law, as illustrated by the Genes on Trial program, the defendant can invoke a reductive and determinist view of behavioral genetics to shift blame away from his "free will" and thus demonstrate either that he lacked the mens rea to commit the offense or that he does not deserve the full extent of punishment because he is not fully culpable for the crime. ${ }^{75}$

\section{B. Effects of Blame Shifting on the Individual, Family, Community, and Society}

When viewed through a determinist lens, behavioral genetics research can create a self-fulfilling prophecy. For example, when an individual learns that she is genetically predisposed to alcoholism, she may react in one of two ways: If she believes her genetic background is only a predisposition and not predestination, she may be more vigilant about not drinking in order to avoid triggering her heightened appetite for alcohol. But if she takes the determinist view and believes that she cannot control her drinking and thus cannot be blamed for becoming addicted to alcohol, she may actually drink more than she would otherwise. ${ }^{76}$ By shifting blame to her genes and away from her individual autonomy, she fulfills the prophecy of genetic determinism.

In some cases, behavioral genetics research may provide "moral relief for stigmatized conditions" by framing the behavioral trait as a "natural" result of

in all their social, historical, and moral complexity, with their genes." NELKIN \& LINDEE, supra note 28 , at 2 .

71. Nelkin, supra note 43 , at 158 .

72. See NELKIN \& LINDEE, supra note 28 , at 128-29.

73. In tort law, for example, a person who causes an injury is deemed to be at fault and thus responsible for compensating the victim of the injury. For a philosophical discussion of the relationship between causal responsibility and moral blameworthiness, see MARION SMILEY, MORAL RESPONSIBILITY AND THE BOUNDARIES OF COMMUNITY (1992).

74. See Andrews, supra note 46 , at 119.

75. See id. at 120-21; see also Nita Farahany \& James E. Coleman, Jr., Behavioral Genetics and Criminal Responsibility: Reconciling Practice with Theory, 69 LAw \& CONTEMP. PROBS. 115 (Winter/Spring 2006).

76. See Allison Morse, Searching for the Holy Grail: The Human Genome Project and Its Implications, 13 J. L. \& HEALTH 219, 241-42 (1999) ("[Research demonstrates that] a person who believes she is an alcoholic, when informed a particular drink contains alcohol, will consume more of the drink than the average person, even if there is no alcohol in the drink."). 
human biology rather than a conscious choice of moral depravity. ${ }^{77}$ Many gay rights activists, for example, welcome research on the so-called gay gene because it responds to charges that homosexuality is "unnatural" and shifts blame away from individual choices. ${ }^{78}$ Indeed, such research was pioneered by gay men, including geneticist Dean Hamer and neuroscientist Simon LeVay. ${ }^{79}$ Some members of the gay community expect genetics research on homosexuality to advance gay rights, as courts have denied gays and lesbians heightened constitutional protection from discrimination precisely because they view homosexuality as "behavioral" and not "immutable" like race and sex." Others point out, however, that attributing homosexuality to a genetic mutation may suggest that gays and lesbians are "abnormal" and that homosexuality can be "cured" like other "disorders." "81 Even more troubling, discovery of a "gay gene" could lead to genetic screening, genetic engineering, and selective abortion of gay fetuses. ${ }^{82}$

Similar dynamics exist with respect to the family. In some instances, behavioral genetics research may shift blame away from the environment that parents create for their children. In the 1950s and 1960s, for example, schizophrenia was blamed on poor parenting, particularly the uncaring mother. ${ }^{83}$ The National Alliance for the Mentally Ill thus supported research on the genetic link to schizophrenia "because it relieved the parents of the mentally ill from blame." ${ }^{\prime 84}$ At the same time, however, parents of the mentally ill fear that they may be blamed for passing on "defective" genes and thus be restricted in their reproductive freedom. ${ }^{85}$

When behavioral genetics research associates a gene with both a deviant behavior and a racial or ethnic community, genetic reductionism and genetic

77. Nelkin, supra note 43 , at 158 .

78. See PETERS, supra note 57, at 97-98; Rothstein, supra note 53, at 96.

79. See, e.g., DeAn Hamer \& PeTER Copeland, The SCIEnce of Desire: The Search For THE GAy GenE AND THE BIOlogy OF BEHAVIOR (1994); Dean H. Hamer et al., A Linkage Between DNA Markers on the X Chromosome and Male Sexual Orientation, 261 SCIENCE 321 (1993); Simon A. LeVay, A Difference in Hypothalamic Structure Between Heterosexual and Homosexual Men, 253 SCIENCE 1034 (1991). For a discussion of this research, see NELKIN \& LINDEE, supra note 28, at 11920, and PETERS, supra note 57, at 98-102.

80. High Tech Gays v. Def. Indus. Sec. Clearance Office, 895 F.2d 563, 573-74 (9th Cir. 1990); Woodward v. United States, 871 F.2d 1068, 1076 (Fed. Cir. 1989).

81. See NELKIN \& LINDEE, supra note 28, at 122 (quoting a National Enquirer headline: "Simple injection will let gay men turn straight, doctors report"); PETERS, supra note 57, at 106-07; Rothstein, supra note 53 , at 96.

82. See NELKIN \& LiNDEE, supra note 28, at 122 (quoting Harvard Law School Professor Janet Halley's prediction that genetic explanations for homosexuality will encourage "the development of anti-gay eugenics"); PETERS, supra note 57, at 107 . The prospect of aborting a gay fetus was the subject of Jonathan Tolins's 1993 Broadway play The Twilight of the Golds.

83. David C. Rowe \& Kristen C. Jacobsen, In the Mainstream: Research in Behavioral Genetics, in BEHAVIORAL GENETICS, supra note 43 , at 12, 14-15.

84. Nelkin, supra note 43, at 167; see also NELKIN \& LiNDEE, supra note 28, at 147; Allan J. Tobin, Amazing Grace: Sources of Phenotypic Variation in Genetic Boosterism, in BEHAVIORAL GENETICS, supra note 43 , at $1-2$.

85. See NELKIN \& LINDEE, supra note 28, at 147; Nelkin, supra note 43, at 167. 
determinism may shift blame to the community itself in the form of racial or ethnic stigma. Because behavioral genetics research draws statistical conclusions about a sample population and not about specific individuals, it is likely that an individual who possesses a trait will not know whether he possesses the gene variant associated with the trait. The only thing he will know is that he is a member of the racial or ethnic group associated with the gene. Because the only known "cause" of the trait is membership in the racial or ethnic group, it is the group itself that bears the brunt of the blame.

By attributing a trait entirely to genetic factors, a reductive and determinist view of behavioral genetics research can also shift blame away from environmental factors created by society. To avoid legal liability and social disapproval for causing medical and behavioral maladies, industries are now funding genetics research to shift blame away from their products. For example, the Ernest Gallo Clinic and Research Center established by Gallo Winery at the University of California San Francisco conducts research on the genetic link to alcoholism. If such a link is established, "some of the social pressure against alcoholic beverages and their purveyors might be deflected onto 'faulty' genes." cancer, ${ }^{87}$ and genetic predisposition to a disease is a common defense in toxic tort litigation. ${ }^{8}$ By locating the cause of the trait in the individual's genome, genetic reductionism shifts blame away from the industry. By framing the trait as predestined and immutable, genetic determinism alleviates pressure for the industry to change the toxic environment that it creates.

Similarly, research that seeks to explain racial or ethnic inequality in terms of genetics both shifts blame away from societal and governmental discrimination and alleviates pressure for society and the state to change the discriminatory environments that they create. Genetic reductionism justifies racial and ethnic inequality as the "natural" result of innate differences. Genetic determinism rejects societal and governmental efforts to eliminate inequality as futile, since such inequality is genetically predestined. ${ }^{89}$ The Bell Curve, for example, argued that social welfare programs and affirmative action are futile because blacks are genetically less intelligent than whites and Asians. ${ }^{90}$ As Dorothy Nelkin concludes:

[B]y locating the source of social problems within the individual, theories of genetic causation also serve political agendas, for they reduce the responsibility of the state.

86. Rothstein, supra note 53, at 96; see also Nelkin, supra note 43, at 160.

87. See Nelkin, supra note 43, at 167 (citing Jon Cohen, Tobacco Money Lights Up a Debate, 272 SCIENCE 488 (1996)).

88. See id.; cf. Karen Rothenberg et al., Genetic Information and the Workplace: Legislative Approaches and Policy Challenges, 275 SCIENCE 1755, 1756 (1997) ("Some state laws provide for genetic testing by employers in order to determine an employee's susceptibility to toxic chemicals or substances in the workplace, even though cleaning up the environment would enhance the working conditions for all employees and would alleviate the need for genetic testing of individual employees.").

89. See Rothstein, supra note 53, at 95 ("[G]enetic determinism is the scientific justification for social inequality, social Darwinism, and the status quo."); see also Nelkin, supra note 43, at 164.

90. PETERS, supra note 57, at 82-83 (describing The Bell Curve's hypotheses). 
Moreover, genetic explanations of behavior translate into moral guidelines about normal, or natural behavior. At the same time, they provide the equivalent of moral absolution, exonerating individuals by attributing antisocial acts to an independent biological force beyond the influence of volition - the DNA. ${ }^{.1}$

\section{Blame Shifting as a Double-Edged Sword in Criminal Law}

Although blame shifting may seem attractive to a criminal defendant, invoking genetic reductionism and genetic determinism to support a criminal defense can be a double-edged sword. As illustrated by the scenario presented in the Genes on Trial program, an individual's decision to introduce evidence of a genetic predisposition toward criminal behavior can backfire on himself, his family, and his community. If the defendant claims that he cannot control his genetic tendency toward violence, the government may turn that against him and argue that he should not be released on bail or given the possibility of parole, as he poses a permanent danger to society. And if this particular defendant has the "gene for aggression," the argument goes, then members of his family and racial or ethnic group likely have the gene too. Nelkin warns: "If it is accepted that genetic endowment determines the propensity to commit bad acts, then hereditary traits, which often reduce to ethnic group membership, may one day be considered evidence of the commission of the crime." ${ }^{\prime 2}$

This possibility is not as remote as one would hope. In a recent case, an Ohio trial court sentenced a Native American defendant, who had been convicted of assaulting two police officers while she was drunk, to quit her job as a waitress in a bar, to refrain from consuming alcohol for two years, to undergo alcoholism counseling, and to "write a paper regarding your [sic]-for educational purposes-on alcoholism and the American Indians. ${ }^{.93}$ During trial, the court asked the defendant's mother whether she knew "anything about genetic predisposition to alcoholism," whether she had "ever been on an Indian reservation," and whether "she had ever seen "the Scotch or Irish drinking." The trial court also asked the defendant's mother whether she was concerned "that her daughter would become 'a flaming alcoholic' because, with such an ethnic background, "there [was] nothing she can do about it.", 95

Similarly, employing genetic reductionism and genetic determinism in a criminal defense may stigmatize those who carry the "faulty" gene in other contexts. When research in the 1960s suggested a link between XYY trisomy and violence, for example, not only did criminal defendants blame their violence on their extra $\mathrm{Y}$ chromosome, ${ }^{96}$ but thousands of law-abiding XYY

91. Nelkin, supra note 43 , at 158.

92. Rochelle Cooper Dreyfuss \& Dorothy Nelkin, The Jurisprudence of Genetics, 45 VAND. L. REV. 313, 331 (1992).

93. State v. Madey, No. 81166, 2002 WL 31429827, at *2 (Ohio Ct. App. Oct. 31, 2002) (emphasis removed) (quoting the trial court).

94. Id. at *1 (quoting the trial court).

95. Id. (alteration in original) (quoting the trial court).

96. See, e.g., cases cited supra note 57 . 
males were stigmatized as "congenital criminals," and hospitals began screening newborns for XYY, potentially for selective abortion." Likewise, when Huntington's disease was raised as part of an insanity defense by a woman who had shot her children, ${ }^{98}$ the Huntington's Disease Society of America worried that the defense would stigmatize all Huntington's sufferers as violent and lead to discrimination in other areas, such as employment. ${ }^{99}$ As theologian Ted Peters puts it: "One possible scenario from such a precedent is that genetic determinism might end up declaring those committing crimes innocent and stigmatizing those not committing crimes as potentially guilty."100

\section{THE DisCREDITING GENE: RACIAL AND ETHNiC STIGMA}

Tracy Islanders are going to be known as the alcoholics of the country. And so whenever I go someplace and they say, "Oh, you're a Tracy Islander," they will say, "Oh, we don't want to hire you." Or they will say, "Oh, you come from that group, that genetically deformed, defective group. You carry the gene for alcoholism."

\section{- Patricia King, Professor, Georgetown University Law Center ${ }^{101}$}

When viewed through the lenses of reductionism and determinism, behavioral genetics research has a unique potential to stigmatize racial and ethnic minority groups. Because of the "discrete and insular" character of these groups, and because of the salience of race and ethnicity in our society, racial and ethnic stigmas are more powerful and pervasive than other types of stigma.

\section{A. Deconstructing Stigma}

The term "stigma" historically refers to a physical mark branded on a criminal or slave to identify the person as dangerous or subhuman. ${ }^{102}$ Like the "A" that marks the adulteress in The Scarlet Letter, a stigma serves as a badge of opprobrium, signaling to society that the individual should be "discredited, scorned, and avoided." 103 Racial and ethnic stigmas are "dishonorable meanings socially inscribed on arbitrary bodily marks," such as skin color, that identify an individual as a member of a racial or ethnic group. ${ }^{104}$ A racially stigmatized

97. See PETERS, supra note 57, at 69-72. See generally DAVID SUZUKI \& PETER KNUdTSON, Genethics: The Clash Between the New Genetics and Human Values 141-59 (1989).

98. Caldwell v. State, 354 S.E. 2 d 124 (Ga. 1987).

99. PETERS, supra note 57, at 66-67; Andrews, supra note 46, at 119-20, 125.

100. PETERS, supra note 57 , at 67.

101. GENES ON TRIAL, supra note 1 (playing the role of a Tracy Islander).

102. See ERving GoffMAN, Stigma: Notes on THE MANAGEMENT OF SPOILEd IdENTITY 1 (1963); R.A. Lenhardt, Understanding the Mark: Race, Stigma, and Equality in Context, 79 N.Y.U. L. REV. 803, 814-15 (2004); see also OXFORD ENGLISH DICTIONARY 689 (2d ed. 1989).

103. Lenhardt, supra note 102, at 814 (quoting Steven L. Neuberg et al., Why People Stigmatize: Toward a Biocultural Framework, in THE SOCIAL PSYCHOLOGY OF STIGMA, supra note 3, at 31, 31).

104. Id. at 809 (quoting GLENN C. LOURY, The ANATOMY OF RACIAL INEQUALITY 59 (2002)). 
person is "reduced in our minds from a whole and usual person to a tainted, discounted one," undeserving of full participation in mainstream society. ${ }^{105}$

Not coincidentally, these definitions of racial and ethnic stigma overlap with the constitutional criteria for "discrete and insular minorities" who, because of their stigmatized social status, require special judicial solicitude. ${ }^{106}$ The notion of stigma provides a conceptual link among the criteria: it is because the discrete marks of race and ethnicity signal inferiority that racial and ethnic minority groups historically have been subject to discrimination and excluded from mainstream society. In addition, just as the discreteness and insularity of racial and ethnic minority groups are what make them "interesting" subjects of genetics research, ${ }^{107}$ they are also what make racial and ethnic stigmas more pernicious than other types of stigma.

In the context of behavioral genetics, the "faulty" gene associated with criminal or antisocial behavior is the mark that identifies the individual as dangerous and subhuman. The potential for racial or ethnic stigma arises when behavioral genetics research associates the faulty gene with a racial or ethnic minority group. ${ }^{108}$ Because the faulty gene cannot be readily perceived and thus serves as a poor signaling device, ${ }^{109}$ the physical marks of race or ethnicity, such as skin color, take its place, serving as outward reflections of the faulty gene. Thus, while the faulty gene stigmatizes those who carry it, the link between the faulty gene and the racial or ethnic minority group stigmatizes all members of the group, regardless of whether they carry the faulty gene.

\section{B. Racial and Ethnic Stigma in Context}

The racial or ethnic stigma that arises from the "faulty" gene is even more powerful when the behavior associated with the gene maps onto preexisting stereotypes about the racial or ethnic group. Because racial and ethnic stigmas are social constructs, their existence and salience depend on the social context in which the behavioral genetics research is conducted. ${ }^{110}$ For example, studying the genetic influence on alcoholism in the Irish or the Native American

105. Id. at 818 (quoting GoFFMAN, supra note 102 , at 3 ).

106. See supra Part II.A. See generally Deborah Hellman, The Expressive Dimension of Equal Protection, 85 MinN. L. REV. 1 (2000). Glenn Loury defines "race" as "a cluster of inheritable bodily markings carried by a largely endogamous group of individuals, markings that can be observed by others with ease, that can be changed or misrepresented only with great difficulty, and that have come to be invested in a particular society at a given historical moment with social meaning. This definition has three aspects: ease of identification, relative immutability, and social signification." LOURY, supra note 104 , at $20-21$. This definition also overlaps with the Supreme Court's definition of "discrete and insular minorities" as those who exhibit "obvious, immutable, or distinguishing characteristics that define them as a discrete group"; those who historically have been subject to discrimination; and those who are a "minority or politically powerless." Lyng v. Castillo, 477 U.S. 635, 638 (1986).

107. GENES ON TRIAL, supra note 1 (Francis Collins).

108. Cf. PETERS, supra note 57, at 73 ("If we identify crime with genes and then genes with race, then we may inadvertently provide a biological support for prejudice and discrimination.").

109. Cf. GOFFMAN, supra note 102, at 43-51 (explaining how stigma symbols convey negative social information and thus must be readily perceived by others).

110. See Lenhardt, supra note 102 , at 821. 
community has greater potential for stigma than studying alcoholism in the Jewish community. Likewise, studying the heritability of aggression in the African American community has greater potential for stigma than studying aggression in the Amish community. ${ }^{11}$

As mentioned above, racial and ethnic stigmas are especially threatening because of the discreteness and insularity of the racial or ethnic minority group. First, because the physical marks of racial and ethnic identity are distinct, observable, and generally immutable, racial and ethnic stigmas are more difficult to avoid by "converting," "passing," or "covering." "II2 In other words, because the groups are discrete and insular, it is more difficult for members of the group to assimilate into the mainstream in order to avoid the shadow of stigma. Second, a history of discrimination, especially genetic discrimination, lends additional resonance to racial and ethnic stigma because it echoes a message that is deeply ingrained in the social psyche. Third, racial and ethnic stigmas reinforce insularity: while stigma encourages the mainstream population to avoid contact with the stigmatized group, it is only through increased social contact between groups that racial and ethnic stereotypes can be dispelled. Finally, the political powerlessness of many racial and ethnic minorities makes the racial and ethnic stigma associated with behavioral genetics research more likely to be translated into social policy. In the Genes on Trial program, Francis Collins pointed out that men are "predisposed to get in trouble with the law at about a tenfold increased risk than [women]."113 But the fact that the $\mathrm{Y}$ chromosome is strongly correlated with crime is not touted as a rationale to change social policy, perhaps in part because most policymakers are men.

\section{The Harms of Racial and Ethnic Stigma}

The harms of racial and ethnic stigma come in various forms. At the individual level, they include heightened anxiety about racial or ethnic bias, self-hate, and stereotype threat. When an individual is stigmatized because of her race or ethnicity, she may feel "insecure and uncertain in interactions with others," constantly fearing prejudice and discrimination. ${ }^{14}$ As a result, she may distrust others and view all her social interactions through the lens of race or ethnicity. At the same time, she may internalize the racial or ethnic stigma that she faces every day. ${ }^{115}$ In Brown $v$. Board of Education, for example, the Supreme Court recognized this form of self-stigma when it observed that segregating schoolchildren by race "generates a feeling of inferiority as to their

111. Cf. id. at 359 (describing the "black beast" stereotype as "a violent brute with an unusually powerful sexual appetite for white women who was completely devoid of humanity").

112. Kenji Yoshino, Covering, 111 YaLE L.J. 769 (2002); see also GoFFMAN, supra note 102 at $73-$ 91, 102-04.

113. See Genes ON TRIAL, supra note 1.

114. Lenhardt, supra note 102, at 839-41; see also GOFFMAN, supra note 102, at 13-14.

115. Lenhardt, supra note 102, at 841-42; see also GOFFMAN, supra note 102, at 7. 
status in the community that may affect their hearts and minds in a way unlikely to ever be undone." threat," a type of performance anxiety that stems from the desire not to confirm negative stereotypes about the racial or ethnic group. ${ }^{17}$

These psychological harms are not necessarily unique to race and ethnicity, but they are more acute when membership in the stigmatized group is important to the individual's personal identity. For example, if being black is an important aspect of one's personal identity but being tall is not, then the message that blacks are genetically predisposed to violence carries more stigmatic harm than the message that tall people are genetically predisposed to violence.

At the group level, the harms of racial and ethnic stigma include discrimination, racial or ethnic profiling, and racial or ethnic stereotyping. ${ }^{118}$ Although these harms are also felt at the individual level, they are attacks on the racial or ethnic community as a whole and represent the experiences of many members of the group. ${ }^{19}$ The harm may be a tangible deprivation of property or liberty, such as being denied a job or being stopped by the police, or it may be an intangible deprivation of dignity, such as being called a racial epithet or being asked whether one knows how to speak English. Like the harms that affect the individual psyche, these harms draw their impact in part from the group's historical and collective experiences. Therefore, the stigmatic harm of behavioral genetics research depends on both the context in which it is conducted and the group on which it focuses.

VI

\section{CONCLUSION}

There is a certain risk here that [the study] could foment prejudice. And the risk arises not just out of the study, but out of the way the study is presented... . And the bigger the mess it is, and the [morel it's about how the study was done, and the more confusing it gets, there's only one thing I remember. And that is that Tracy Islanders drink a lot. . . I'm committed to research, so I might do it anyway. But nonetheless, there's a point here.

- Justice Stephen Breyer, United States Supreme Court ${ }^{120}$

In the Genes on Trial program, the hypothetical research on "the alcoholism gene" in Tracy Islanders had no immediate clinical application. ${ }^{121}$ It did,

116. 347 U.S. 483,494 (1954).

117. Lenhardt, supra note 102, at 843-44 (citing Claude M. Steele \& Joshua Aronson, Stereotype Threat and the Intellectual Test Performance of African-Americans, 69 J. PERSONALITY \& SOC. PSYCHOL. 797 (1995)). For a review of the recent literature on stereotype threat, see S. Christian Wheeler \& Richard E. Petty, The Effects of Stereotype Activation on Behavior: A Review of Possible Mechanisms, 127 PSYCHOL. BULL. 797 (2001).

118. See Lenhardt, supra note 102, at 836-39.

119. See id. at 836.

120. GENES ON TRIAL, supra note 1 (playing the role of the uncle).

121. Id. (Francis Collins). 
however, have an immediate stigmatic impact on the Tracy Islander community. In concluding the program, Charles Ogletree asked: "Should any of this scientific inquiry be off limits?"

For many scientists, this question is blasphemous, as they view all scientific knowledge as inherently valuable, no matter what its social and political consequences. Others point to the promise of improving the human condition through scientific inquiry: "If we want to see a better day for medical treatments, for public health, for improving our lot, for reducing suffering, it is this engine of research that will get us there."123 But even if behavioral genetics research could theoretically lead to a "cure" for antisocial behavior, this benefit is unlikely, whereas the harm of racial and ethnic stigma is all too likely, as our history has shown. ${ }^{124}$ Moreover, although "curing" alcoholism is almost certainly beneficial to the individual's health and to society's productivity, there would be less consensus about other traits, such as homosexuality and impulsiveness. Is the scientific ability to change these behaviors beneficial to the individual or to society? Or is it a frightening move toward eugenics? In a world of limited resources, should we fund research that has remote benefits but obvious harms?

It is unlikely that the tide of behavioral genetics research can be, or even should be, stopped. But in answering these questions, and in deciding who and what to study, we must consider the implications of behavioral genetics research for the individual, the family, the community, and society. We should question not only the purpose of the study, but whether a strong scientific justification supports focusing on a racial or ethnic minority group. We should consider who is being studied, what is being studied, and who is doing the study. It is through heightened sensitivity to the context of behavioral genetics research that we can try to avoid the stigma of a "scarlet gene."

122. Id. This same question was asked in 1992 when David Wasserman at the University of Maryland planned a conference on "Genetic Factors in Crime: Findings, Uses, and Implications." In response to public protest and outcry from the African American community, the National Institutes of Health revoked its funding, and the conference was canceled. See PETERS, supra note 57, at 72-73.

123. Genes on TRIAL, supra note 1 (Francis Collins).

124. See Stevens, supra note 16, at 1070; $c$ f. Rothenberg, supra note 30, at 106-07. 